\author{
Endy Nahya Ardini' ${ }^{1}$, Titihan Sarihati ${ }^{2}$ \\ Telkom University \\ 1endynahyaardini33@gmail.com, \\ 2titihansarihati@tcis.telkomuniversity.ac.id
}

\title{
PENGARUH WARNA PADA ELEMEN INTERIOR RUANG TUNGGU RUMAH SAKIT IBU DAN ANAK TERHADAP PSIKOLOGIS PENGUNJUNG (Studi Kasus Rumah Sakit Ibu dan Anak Melinda Bandung)
}

\begin{abstract}
Abstrak. Rumah sakit merupakan sarana kesehatan yang vital di setiap wilayah. Sebagai sarana yang memberikan jasa kesehatan, rumah sakit sering menimbulkan efek psikologis pada penggunanya. Salah satu yang memberi efek psikologis adalah warna. Rumah sakit ibu dan anak menuntut desain khusus yang lebih steril dan memiliki efek psikologis sesuai dengan kebutuhan mereka. Psikologis setiap pengguna dirumah sakit berbeda baik pasien wanita, anak, pengantar, mauppun petugas di rumah sakit itu sendiri. Bangunan rumah sakit memiliki fungsi pemeriksaan dengan waktu yang dapat dibilang sementara (non permanen). Diantara area-area yang ada pada rumah sakit, ruang tunggu merupakan area yang berpengaruh besar untuk dijadikan penilaian sebuah rumah sakit dikarenakan area ini yang dapat dimasuki oleh semua kalangan pengunjung. Dengan segala fungsi dan sifatnya, maka desain yang terdapat pada area ruang tunggu haruslah dapat cepat ditangkap dan direspon oleh pengguna. Warna merupakan salah satu aspek visual tercepat yang dapat ditangkap dan direspon oleh manusia diantara aspek visual lain. Oleh karena itu, warna memiliki pengaruh yang besar dalam membentuk suasana dan mempengaruhi psikologis pengguna dalam sebuah ruangan. Termasuk di Rumah Sakit Ibu dan Anak Melinda Bandung yang merupakan Rumah Sakit Ibu dan Anak kelas A yang. Metode observasi dan analisa terhadap pengunjung di area tunggu Rumah Sakit Ibu dan Anak Melinda dilakukan untuk mengetahui seberapa besar pengaruh warna terhadap psikologis pengunjung.
\end{abstract}

Kata Kunci : Warna, Psikologis, Kesehatan, Rumah Sakit.

Abstract. Hospitals are vital health facilities in every region. As a means of providing health services, hospitals often have psychological effects on their users. One that gives a psychological effect is color. Maternal and child hospitals require special designs that are more sterile and have a psychological effect according to their needs. Psychologically every user in the hospital is different from female patients, children, introduction, and even the officers in the hospital itself. Hospital building has the function of examination with a time that can be spelled out while (non permanent). Among the areas that exist in the hospital, waiting room is an area of great influence to be assessed a hospital because of this area that can be entered by all circles of visitors. With all the functions and characteristics, then the design contained in the waiting room area should be quickly captured and responded by the user. Color is one of the fastest visual aspects that can be captured and responded by humans among other visual aspects. Therefore, color has a great influence in shaping the atmosphere and affects the user psychologically in a room. Including at Maternal and Child Hospital Melinda Bandung which is Hospital of Mother and Child class A. Methods of observation and analysis of visitors in the waiting area Maternal and Child Hospital Melinda done to find out how much influence color to psychological visitors.

Key Word : Color, Psychological, Health, Hospital. 


\section{Pendahuluan}

\subsection{Latar Belakang}

Dalam tatanan sarana dan prasarana suatu wilayah, sarana kesehatan publik memiliki peraran penting untuk menunjang kesehatan penduduknya. Salah satu sarana kesehatan publik adalah rumah sakit. Rumah sakit sebagai sarana yang memberikan jasa kesehatan dapat menimbulkan efek psikologis pada penggunanya. Rumah sakit dianggap menyeramkan dengan segala perlakuan medis dan alat-alat yang digunakan untuk penunjangnya. Warna yang diterapkan pada elemen ruang sebuah rumah sakit merupakan salah satu faktor yang memiliki pengaruh terhadap kesan psikologis yang ditimbulkan.

Salah satu rumah sakit yang memerlukan perhatian desain khusus adalah Rumah Sakit Ibu dan Anak (RSIA). RSIA merupakan rumah sakit yang khusus melayani pemeriksaan ibu hamil, ibu yang akan melahirkan, dan kesehatan anak. Mangacu pada Peraturan Menteri Kesehatan RI No. 24 Tahun 2016 Tentang Persyaratan Teknis Bangunan dan Prasarana Rumah Sakit, kebutuhan di RSIA tentu berbeda dengan rumah sakit pada umumnya, RSIA menuntut desain khusus yang lebih steril dan memiliki efek psikologis sesuai dengan kebutuhan mereka.

Di kota Bandung, RSIA Melinda merupakan salah satu RSIA swasta kelas A dengan konsep khas yaitu galery dan hotel bintang lima. Pengunjung RSIA bukan seluruhnya pasien yang sedang sakit, tetapi ada juga yang hanya berkonsultasi, mengantar, atau pun menjenguk. Dalam hal ini, peran warna di area tunggu yang merupakan area publik dan perantara diharapkan dapat memberi efek psikologis yang dapat mengalihkan perhatan pengunjung, dari kesan menakutkan dan memberi efek nyaman untuk aktivitas menunggu, serta dapat mengurangi ketegangan wanita atau ibu sebelum diperiksa, melahirkan, serta aktivitas lainnya. Selain itu ruang tunggu sebaiknya dapat menjauhkan dari hal-hal yang mengakibatkan traumatik agar pengunjung terutama bagi pasien anak-anak tidak merasa takut kerena bagi seorang anak, rumah sakit adalah tempat asing dengan orang-orang asing yang dapat mengganggu kondisi emosionalnya.

Sebagaimana ruang tunggu pada bangunan publik lain, ruang tunggu pada bangunan rumah sakit juga memiliki fungsi untuk menunggu. Subjek yang menunggu di klasifikasikan berdasarkan usia yaitu anak-anak dan dewasa. Dengan demikian, berarti ruang tunggu pada RSIA sebaiknya memiliki dua karakter yang memenuhi kebutuhan subjek tersebut untuk mewujudkan efek psikologis yang diharapkan.

Dalam hubungan kedekatan ruang, ruang tunggu padabangunan rumah sakit harus dekat dengan ruang-ruang yang bersinggungan dengan pengunjung, seperti lobi, area pendaftaran dan administrasi, farmasi, poliklinik, rawat inap, tindakan maupun terapi.

Pada kasus ini, RSIA Melinda Bandung memiliki beberapa ruang tunggu dengan elemen interior yang sama. Seluruh dinding dan ceiling menggunakan warna putih tulang, untuk lantai sebagian besar menggunakan dengan material marmer dengan warna cream dan material vinyl motif parket dengan warna coklat. Untuk furniture menggunakan warna-warna coklat dan hitam. Sesuai konsep awal yaitu galery dan hotel bintang lima, penggunaan warna tersebut menimbulkan kesan elegan dan mewah, namun disis lain memiliki efek kejenuhan karena kurangnya aksen warna. Dengan kondisi tersebut, kasus yang sering dijumpai adalah kejenuhan terlebih pada persen anak-anak karena mereka merasa area tersebut tidak menyenangkan ditambah tidak adanya area 


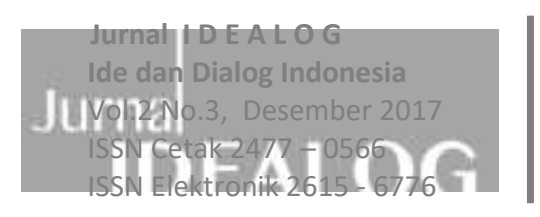

bermain dan ornamen anak-anak disekitar ruang tunggu poli anak sehingga mengakibatkan anak-anak rewel saat menunggu dan mengganggu pasien lain.
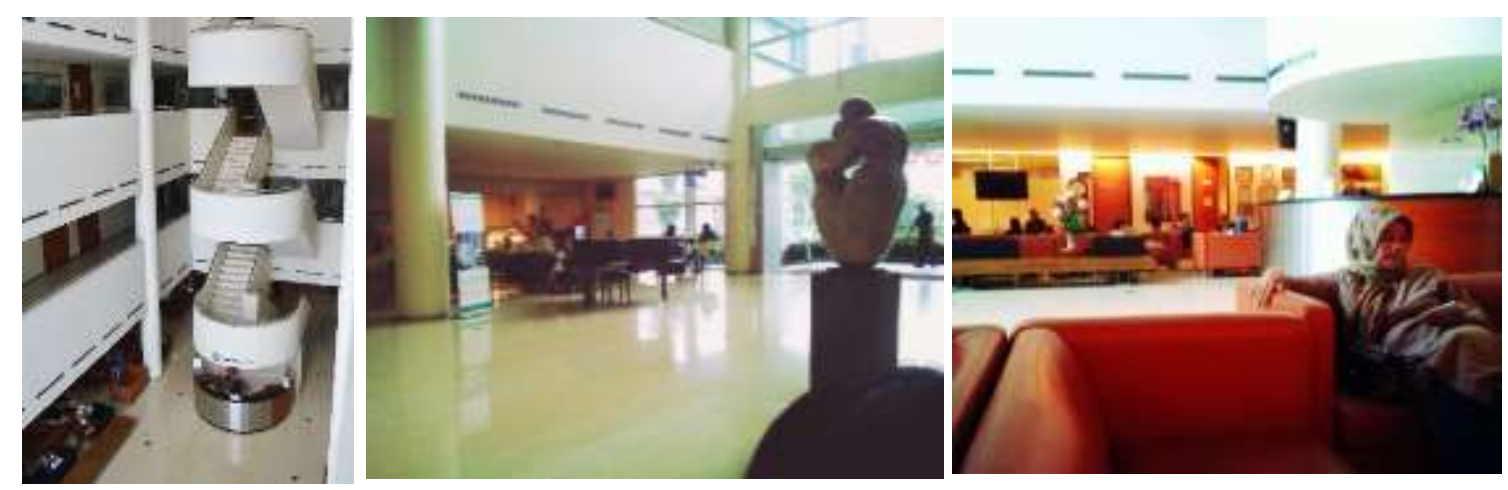

Gambar Foto area lobi dan ruang tunggu lantai satu RSIA Melinda Bandung Sumber : Dokumen RSIA Melinda dan dokumentasi pribadi

\section{Kajian Literatur}

\subsection{Elemen Pembentuk Ruang Interior}

Elemen pembentuk ruang interior merupakan gabungan dari beberapa bidang yang jika salah satunya tidak ada, maka tidak dapat dikatakan ruang interior.

Menurut Wicaksono dan Tisnawati (2014:11), terdapat empat elemen dasar yang menjadi pembentuk ruang interior yang akan membentuk volume (panjang $\mathrm{x}$ lebar $\mathrm{x}$ tinggi) sebuah ruangan :

- Lantai sebagai bidang bawah

- Dinding sebagai bidang tengah/ penyekat

- Plafon sebagai bidang atas

- Berbagai bukaan yang dapat diaplikasikan ke dalam tiga bidang dimnsional diatas

- Elemen pengisi ruang yang disebut juga perabot /furniture, biasanya berwujud kursi, meja, ranjang, lemari, lukisan, vegetasi, lampu dll.

Dari teori diatas, maka dapat disimpulkan bahwa elemen pembentuk ruang interior terdiri dari lantai, dinding, plafon, bukaan, serta elemen pengisi ruang adalah furniture.

\subsection{Psikologi Dalam Interior}

Menurut KBBI, psikologis atau psikis adalah hal yang berkaitan dengan kondisi jiwa seseorang. Psiklogis setiap individu dapat dipengaruhi oleh emosional yang dipicu lingkungan sekitar. Pada setiap jenjang umur, manusia akan terus mengalami perubahan psikologis dalam merespon sesuatu.

Faktor eksternal yang dapat mempengaruhi konsisi psikologis manusia adalah melalui interaksi antar individu dan melalui visual. Dalam konteks perancangan interior ruang, visual maupun interaksi antar individu ditujukan untuk menghadirkan kenyamanan. 
Kenyamanan sendiri memiliki kriteria khusus dalam setiap kondisi. Dalam kondisi sebuah sarana pelayanan kesehatan terutama di rumah sakit ibu dan anak, tentu objek utama yang menjadi perhatian untuk dipenuhi kebutuhannya adalah ibu dan anak. Simonds dalam bukunya berjudul Arsitektur Lanscape menyebutkan karakter ruang yang direncanakan secara khusus untuk menimbulkan respon emosi serta psikologis yang dikehendaki guna mengurangi beban psikologis pasien, penyembuhan ini bisa menggunakan terapi visual yang antara lain warna, bentuk, tekstur, skala serta layout ruang. Terapi visual ini bisa menimbulkan efek psikologis, antara lain:

- Ketenangan

Dalam realisasi penerapan visual, ketenangan dapat diwujudkan dengan sifat sederhana, memiliki objek dan material yang tidak asing, warna lembut seperti putih, abu-abu, hijau, atau biru, dan memiliki bentuk lengkung yang jelas.

- Kenyamanan

Sedangkan kenyamanan sendiri memiliki arti bahwa segala aspek interior dan suasana sesuai dengan pengguna, baik itu bentuk, warna, tekstur, simbol, tanda, bunyi, cahya, dll), warna-warna yang sesuai dengan pasien dalam ruang tersebut juga sangat berpengaruh untuk kenyamanan.

- Keakraban

Keakraban sendiri tercipta dari perasaan intim dan tidak asing, dalam penerapannya pada elemen interior, keakraban di visualisasikan dengan garis mengalir, langit-langit yang remdah, bentuk fleksibel, memiliki pusat, dan elemen warna yang ringan.

\subsection{Warna Dan Efek Psikologis Yang Ditimbulkan}

Pada banyak penelitian mengenai kerterkaitan warna dengan kehidupan manusia, diperoleh hasil bahwa dapat mempengaruhi jiwa dan emosi manusia serta mempengaruhi kegiatan fisik dan mental. Dalam penelitian yang dilakukan oleh Birren, diketahui bahwa warna mempengaruhi aktivitas otak, detak jantung, tekanan darah, dan pernafasan. Warna juga dapat mengungkapkan sifat kewanitaan dan kejantanan, Wanita lebih menukai warna yang lembut, pastel, dan hangat. Sedangkan pria lebih menyukai warna yang tegas, sejuk dan tua.

Terdapat warna-warna yang memiliki rangsangan sifat dan emosi manusia yang dijelaskan oleh Marial L. Davis dalam buku Design in Dress (1987:135), beberapa diantaranya yaitu :

Kuning : cerah, bijkasana, terang, bahagia, hangat.

Hijau muda : Segar, kaya, tenang, tumbuh.

Biru : Menahan diri, lembut, damai, depresi, pasif terhormat, setia.

Coklat : Tenang, hangat, bersahabat, alami, tenang, kebersamaan, rendah hati, sentosa.

Putih : Cinta, senang, murni, harapan, lugu, pemaaf, bersih, cinta, tenang.

Merah : Cinta, kekuatan, keberanian, menarik, vitalitas, pengorbanan.

Dalam sebuah bangunan rumah sakit, penggunaan warna terkait dengan hal-hal untuk permasalahan perawatan dan pelayanan kesehatan mental maupun fisik manusia. Penggunaan warna dalam hal ini adalah guna membantu usaha-usaha pelayanan dalam 
rumah sakit tersebut dimana manusia dalam kondisi ini memiliki temperamen khusus yang penuh emosional.

Kelembutan dan kekuatan warna mengundang perubahan emosional. Untuk pasien sendiri, terdapat warna-warna yang disarankan, diantaranya: warna hangat; nada koral, nada buah persik, kuning, warna sejuk; hijau terang dan aqua. Untuk ruangan dengan sifat menunggu atau ruang perawatan biasa, bisa digunakan warna putih oyster, warna pasir, kuning lembut (beige) dengan aksen terra cotta atau hijau emerald, turquoise, biru safir, flaminggo, merah labu. (A.Sulasmi Darmaprawira W. (2001 : 30, 37-38, 135137))

\subsection{Psikologi Manusia Dalam Rumah Sakit Ibu dan Anak}

1) Wanita/Ibu

Salah satu pengguna yang mendominasi dirumah sakit ibu dan anak adalah wanita, baik sebagai seorang yang ingin berkonsultasi perihal kehamilan, sebagai seorang calon ibu yang memeriksakan kandungannya maupun sebagai seorang ibu yang mengantarkan anaknya.

Wanita yang sedang hamil mengalami tingkat kenaikan emosi dan tekanan batin pada kondisi psikisnya. Wanita yang merasa bahagia dengan kehamilannya cenderung merasa bangga dan bergairah menyambut bayinya yang akan lahirAhmad Darto dalam bukunya yang berjudul Psikologi Kebidanan menyebutkan wanita memiliki sifat yang lebih peka dan estetis ketika memasuki usia dewasa, estetis tersebut biasanya ia salurkan dalam hal penataan barang-barang disekitarnya dan dalam har berhias/berdandan.

Selain itu keadaan wanita yang datang ke rumah sakit ibu dan anak umumnya tingkat stress mereka akan naik disebabkan oleh faktor kecemasan karena kekhawatiran akan kondisi bayi, kesiapan/tingkat kematangan emosi, tentang bentuk badan, problem genetik, dan perubahan peraturan ketika masa kehamilan.

Dari beberapa sumber diatas, dapat disimpulkan bahwa psikologi wanita ketika sebelum hamil adalah menyukai hal-hal yang indah dan ketika seorang wanita hamil, ia akan mengalami perubahan emosional, pada umumnya wanita hamil merasa antusias menunggu kelahiran bayinya, namun dalam keantusiasan tersebut terdapat perasaan cemas dan tegang yang disebabkan beberapa faktor. Kecemasan dan ketegangan tersebut akan bertambah ketika wanita datang ke rumah sakit. Oleh karena itu, desain rumah sakit yang jauh dari kesan menakutkan dan memberi ketenangan sangat dibutuhkan untuk menekan tingkat ketegangan tersebut.

1) Anak

Seorang anak memiliki karakter disetiap jenjang pertumbuhannya. Kesehatan anak maupun proses penyembuhan penyakit sangat dipengaruhi oleh faktor lingkungan. Rumah sakit bagi seorang anak merupakan tempat asing karena berbeda dengan lingkungan sekitar tempat tinggalnya. Akibatnya, gangguan emosional sering muncul dan adakalanya hal ini berpengaruh pada proses penyembuhan. Sehingga proses penyembuhan penyakit pada anak dibutuhkan persyaratan khusus dalam perawatannya yang berbeda dengan orang dewasa (persyaratan medis, maupun pelayanan psikologis), seperti: struktur anatomis, kondisi biologis maupun psikologisnya. 
Hal-hal yang terjadi dan ditanamkan pada diri seorang anak akan membekas pada dirinya sebagai entry point yang mengawali proses tumbuh kembangnya dan memberikan warna dasar pada kepribadiannya. Pada kasus keberadaan anak di rumah sakit, suasana yang kurang bersahabat dengan dunia mereka akan menimbulkan kesan pertama yang buruk dan menakutkan bagi anak, sehingga mind set yang ada pada anak adalah rumah sakit merupakan tempat yang menakutkan. Efeknya akan membuat proses penyembuhan menjadi terhambat, karena salah satu proses penyembuhan adalah dari dalam diri anak sendiri.

2) Psikologi anak saat sakit

Setiap pasien anak yang sedang sakit, selain merasakan sakit yang sering di ekspresikan dengan rewel akibat penyakitnya, mereka juga mendapatkan efek psikologis dari lingkungan tempat perawatannya dan juga proses perawatannya yang dapat menimbulkan tekanan dan beban mental bagi pasien. Seorang anak merasa beban mental tersebut lebih berat dari rasa sakit akibat penyakit yang sedang dideritanya, perasaan yang menjadi beban meliputi hal-hal sebagai berikut

- Perasaan tertekan, merupakan adanya rasa rendah diri yang membuat anak merasa tertekan.

- Jenuh, merasa tidak nyaman dari dalam dirinya yang menyebabkan perawatan terasa menjadi lebih lama.

- Meninginkan kebersamaan, ingin kehadiran orang tuanya, keluarganya, ataupun bersama dengan teman yang sama-sama sakit (sependeritaan).

- Meninginkan lingkungan yang sesuai dengan dunianya (dunia anak), anak-anak butuh lingkungan yang sesuai dengan apa yang mereka sukai untuk melepaskan beban psikologisnya.

Anak-anak yang datang ke rumah sakit ibu dan anak adalah ia yang memiliki masalah pada keadaan tumbuh kembang ataupun mengalami sakit. Anak-anak ketika tiba dirumah sait memiliki rasa takut yang tinggi terlebih ketika bertemu dengan dokter. Anak-anak akan merasa takut dan menangis melihat dokter dan peralatannya. Tidak banyak pengalaman anak mengenai rumah sakit, sehingga apa yang dilihat saat ia dirumah sakit haruslah jauh dari kesan menyeramkan agar tidak menimbulkan kesan traumatik. Anak-anak akan teralihkan perhatiannya dengan permainan dan bentuk serta warna-warna yang membuat mereka senang.

3) Pengantar

Menurut analisa yang dilakukan, pengantar sebagian besar adalah wanita, dan beberapa adalah laki-laki. Kondisi pengantar pasien di rumah sakit biasanya mudah bosan, khawatir, dan mudah tertular, sehingga kenyamanan bagi para pengantar adalah ruangan dengan kondisi tidak berdekatan anatar kursi ruang tunggu dan adanya warnawarna tidak monoton. Pengantar pasien juga memiliki peran penting dalam proses hadirnya ketenangan pada pasien, jika pengantar pasien tenang dan merasa senang, maka ia akan dapat menularkan apa yang ia rasakan pada pasien yang diantar. Namun apabila pasien juga merasa bosan dan khawatir, maka perasaan pasien yang diantar juga akan terpengaruh.

4) Petugas 
Petugas yang bekerja disekitar area tunggu seperti petugas adaministrasi, faramasi, dan beberapa perawat dengan tugas mendata pasien memerlukan pikiran yang tenang dan fokus. Dengan tuntutan tersebut, kondisi area petugas haruslah didesain dengan desain yang mampu membuat petugas merasa nyaman menghadapi berbagai pasien dan pengunjung setiapharinya. Petugas juga harus mampu mengendalikan emosinya untuk menghadapi pasien dengan karakter yang berbeda-beda setiap waktunya.

\section{Metode Penelitian}

Jenis penelitian yang akan dilakukan adalah deskriptif kualitatif, dimana pencarian fakta mengenai pengaruh warna di area tunggu Rumah Sakit Ibu dan Anak Melinda Bandung melalui pengamatan lapangan. Dari hasil observasi lapangan tersebut, dilakukan metode enelitian sebagai berikut:

\subsection{Metode Observasi}

Melalui pengamatan terhadap area tunggu pada lantai satu dan lantai tiga yang merupakan ruang tunggu poliklinik. Variabel yang digunakan adalah perilaku pengguna yang mencerminkan tingkat kenyamanan di lokasi tersebut. Tahapan dalam melakukan observasi ini antara lain:

- Melakukan survey lapangan di Rumah Sakit Ibu dan Anak Melinda yang beralamatkan di Jl. Raya Padalarang, Kertajaya, Padalarang, Kabupaten Bandung Barat, Jawa Barat.

- Melakukan wawancara dengan pihak pengelola untuk mengetahui kegiatan di setiap area ruamh sakit (terutama di zona publik) dan mengetahui jumlah rata-rata pengunjung setiap harinya.

- Observasi lapangan pada jam-jam praktek dokter yaitu mulai pukul 07.00-23.00 WIB selama beberapa hari.

- Menganalisa hasil pengamatan dari objek dan subjek yang dituju (perlilaku pengunjung terhadap warna-warna pada elemen interior rumah sakit)

\subsection{Metode Analisis Data}

Terdapat dua area tunggu dengan penggunaan warna sedikit berbeda di Rumah Sakit Ibu dan Anak Melinda Bandung yang akan menjadi objek analisa. Analisa dilakukan dengan variabel :

- Arah warna yang banyak dituju dan dilihat pengunjung (lantai, dinding, ceiling, furniture)

- Persentase pengunjung di area tunggu (wanita, pria, anak)

- Perilaku pasien wanita (tingkat tenang-gelisah)

- Perilaku pasien anak (tingkat tenang-gelisah)

- Perilaku pengantar pasien (tingkat tenang-gelisah)

Analisa dilakukan dengan pengamatan dari beberapa titik, yaitu titik A merupakan area tunggu untuk poli anak, klinik laktasi dan farmasi, titik B merupakan area tunggu umum sekaligus cafe, titik $\mathrm{C}$ merupakan area tunggu poli kebidanan dan kandungan. Dan titk D pada gambar dibawah juga merupakan poli kebidanan dan kandungan. 


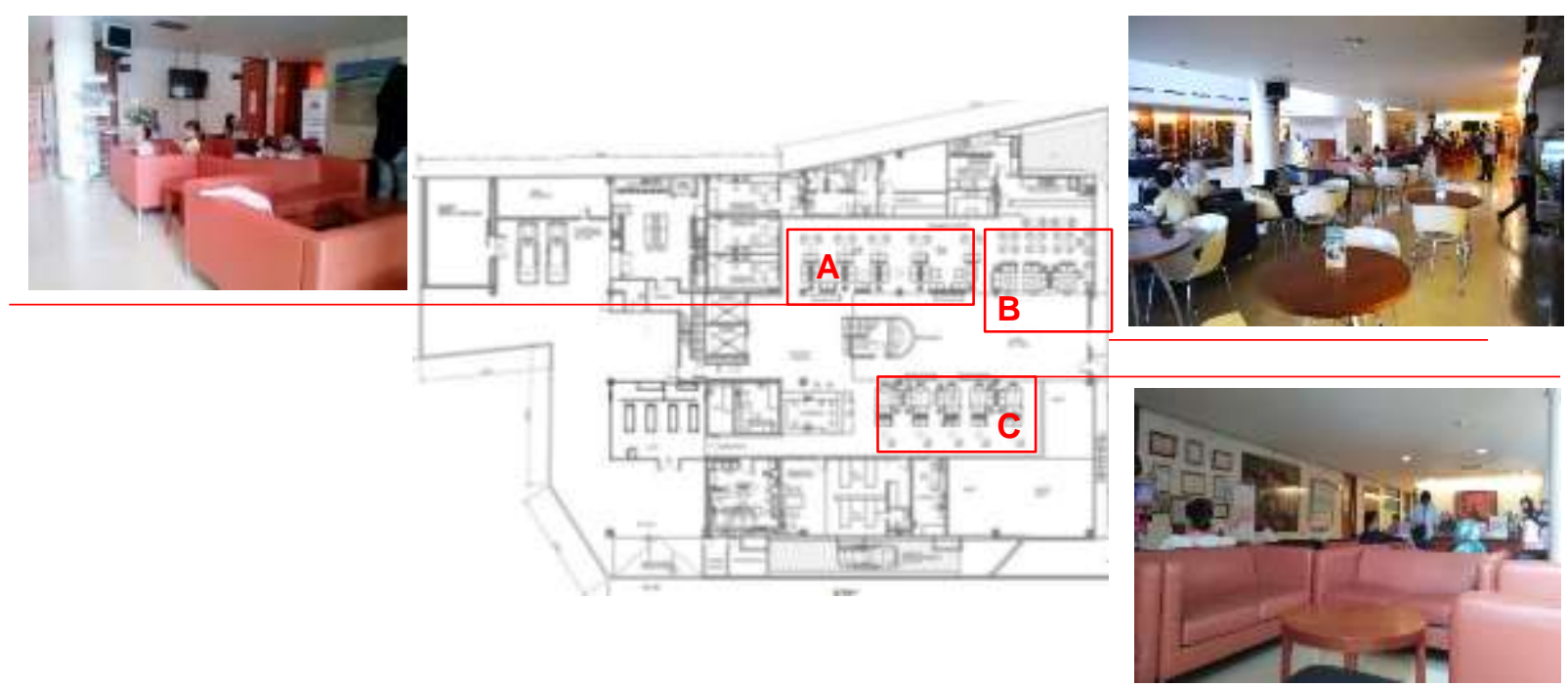

Gambar Denah lantai dasar dan foto ruang tunggu lantai dasar Sumber : Dokumen RSIA Melinda dan dokumentasi pribadi

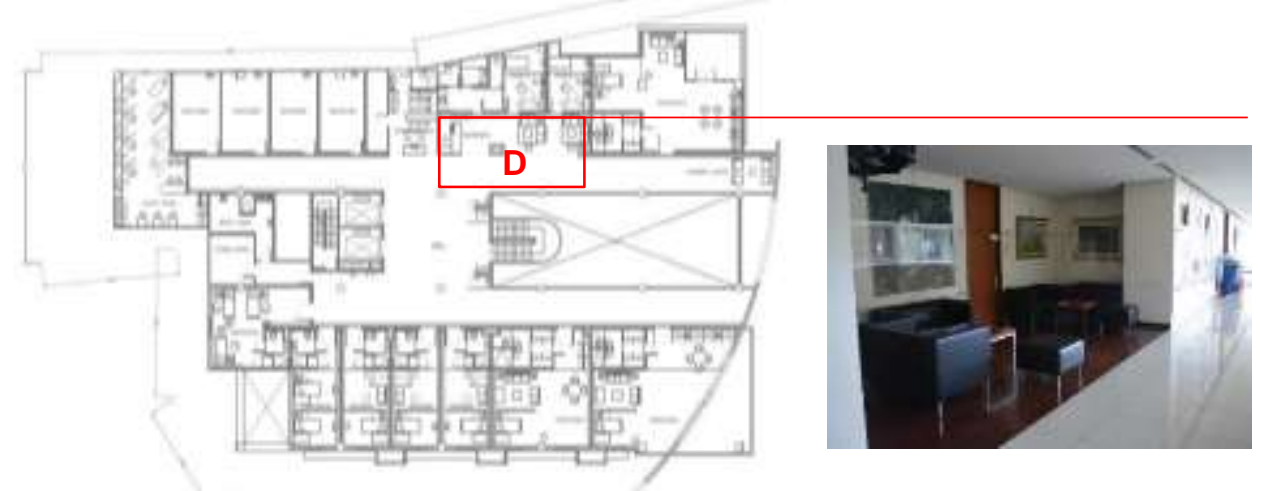

Gambar Denah lantai 3 dan foto ruang tunggu lantai 3

Sumber : Dokumen RSIA Melinda dan dokumentasi pribadi

\section{Hasil \& Pembahasan}

\subsection{Persentase Warna Yang Digunakan Pada Elemen Interior Ruang Tunggu Rumah Sakit Ibu dan Anak Melinda}

Dari pengamatan yang dilakukan, area tunggu pada titik A, B, C dan D memiliki persentase terhadap penggunaan warna padaceiling, dinding, lantai dan furniture sebagai berikut : 

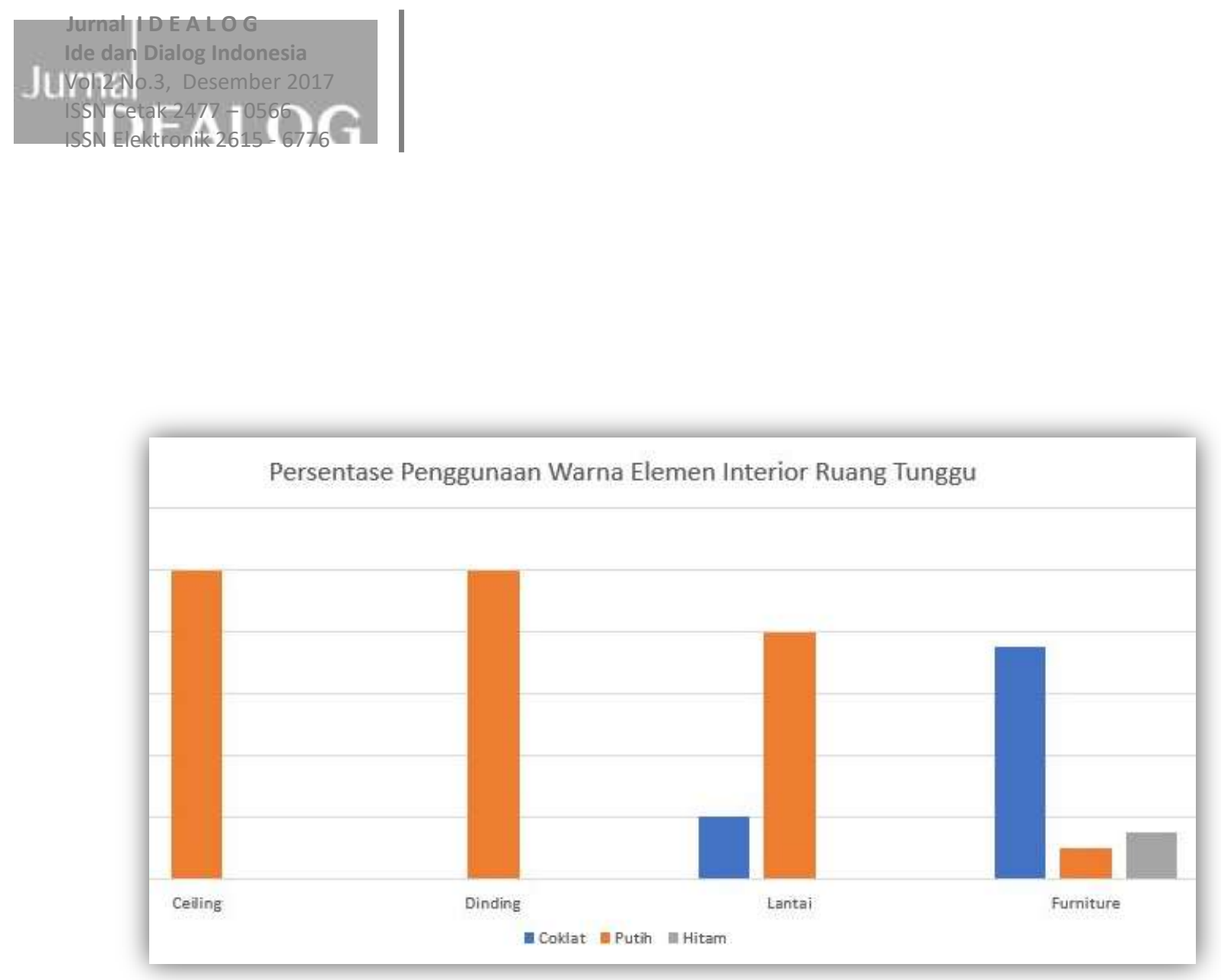

Grafik Persentase Warna Elemen Interior Ruang Tunggu Rumah Sakit Ibu dan Anak Melinda Sumber: Analisa Penulis

Dari grafik tersebut, diperoleh hasil bahwa warna putih mendominasi dengan penggunaannya pada seluruh dinding dan ceiling, hanya pada furniture dan lantai yang menggunakan warna lain selain warna putih.

Jika dikaji dari teori penggunaan warna area tunggu dirumah sakit seperti yang sudah dijelaskan sebelumnya, maka belum sepenuhnya warna yang digunakan dapat memberi efek menenangkan dan lembut seperti warna pastel dan aksen seperti hijau, biru, pink, dan turquoise. Satu satunya warna yang mendekati adalah warna cream pada lantai marmer yang berwarna putih tulang dan warna furniture coklat yang mendekati warna aksen warna terracotta.

\begin{tabular}{|l|l|l|}
\hline \multirow{2}{*}{ RSIA Melinda } & Putih tulang pada marmer & Coklat pada furniture \\
\cline { 2 - 3 } & & \\
\hline Teori & & Warna terracotta \\
\cline { 2 - 3 } & Warna Baige & Wa \\
\hline
\end{tabular}

Tabel Perbandingan Warna Yang Digunakan dan Warna Yang Disarakan Sumber : Analisa Penulis (2017)

Dari analisa juga didapatkan bahwa penggunaaan warna tersebut masi dihubungkan dengan warna yang digunakan untuk memunculkan suasana galery dan hotel bintang lima, sehingga warna yang dipilih cenderung kepada warna elegan dan hangat. 


\subsection{Persentase Pegunjung Pada Area-Area di Ruang Tunggu}

Menurut UU RI Nomor 23 Tahun 2002 pasal 1 Ayat 1, Anak adalah seseorang yang belum berusia 18 tahun, termasuk anak yang masih dalam kandungan. Sedangkan menurut definisi WHO, batasan usia anak adalah sejak anak di dalam kandungan sampai usia 19 tahun. Pengamatan persentase pengunjung yang digolongkan pada jenis kelamin sesuai usia diperoleh hasil sebagai berikut :

\begin{tabular}{|l|c|c|}
\hline \multicolumn{1}{|c|}{ Jenis } & Usia & Persentase \\
\hline Anak - anak & $0-19$ & $15 \%$ \\
\hline Wanita & \multirow{2}{*}{$19+$} & $65 \%$ \\
\cline { 1 - 1 } Pria & & $20 \%$ \\
\hline
\end{tabular}

Tabel Persentase pengunjung di ruang tunggu RSIA Melinda Sumber : Analisa penulis (2017)

Keterangan jenis pengunjung :

- Anak-anak

Pasien anak-anak yang datang didampingi orang tuanya.

- Wanita

Wanita yang datang 50\% datang dengan keluarganya dan $17 \%$ datang sendiri untuk melakukan pemeriksaan, $30 \%$ datang untuk mengantar anak atau keluarganya. Sisanya datang hanya untuk berkunjung.

- Laki-laki

Laki-laki yang datang beberapa diantaranya untuk melakukan konsultasi bersama pasangannya, dan $80 \%$ datang untuk mengantar anak atau pasangannya.

\subsection{Pengaruh Warna di Ruang Tunggu Pada Pasien Wanita}

Dari ke empat titik area tunggu yang di amati, wanita sebagai pasien maupun non pasien hampir memiliki sisi psikologis yang sama, yaitu terlihat lebih cemas. Pengamatan dijabarkan pada tabel berikut:

\begin{tabular}{|c|c|c|l|}
\hline $\begin{array}{c}\text { Titik Area } \\
\text { Tunggu } \\
\text { Wanita/orang }\end{array}$ & $\begin{array}{c}\text { Jumlah } \\
\text { total pengunjung }\end{array}$ & \multicolumn{1}{c|}{ Perilaku terhadap warna } \\
\hline A & $5-15$ & $\pm 70 \%$ & $\begin{array}{l}\text { Diarea ini, wanita sebagai pasien berada di dekat } \\
\text { area farmasi untuk menunggu obat, dan sisanya } \\
\text { mengantarkan anaknya di area tunggu poli anak. } \\
\text { Dari beberapa sofa tunggu yang ada, wanita } \\
\text { cenderung duduk dekat dengan dinding dan } \\
\text { sebagian lain lebih ke sisi luar yang lebih terang. } \\
\text { Sehingga diosisi tengah lebih banyak kosong. }\end{array}$ \\
\hline B & $5-10$ & $\pm 50 \%$ & $\begin{array}{l}\text { Area B merupakan area tunggu umum sekaligus } \\
\text { cafe. Di area ini wanita lebih banyak duduk di } \\
\text { set meja makan dengan warna putih meskipun } \\
\text { terdapat sofa hitam di sisi luar. }\end{array}$ \\
\hline $\mathrm{C}$ & $5-20$ & $\begin{array}{l}\text { Area ini merupakan area tunggu adminstrasi } \\
\text { sekaligus area tunggu poli kebidanan dan } \\
\text { kandungan memliki jumlah wanita yang banyak } \\
\text { dan terkesan lebih padat dari area yang lain. } \\
\text { Namun jika ditinjau dari pengaruh terhadap }\end{array}$ \\
\hline
\end{tabular}




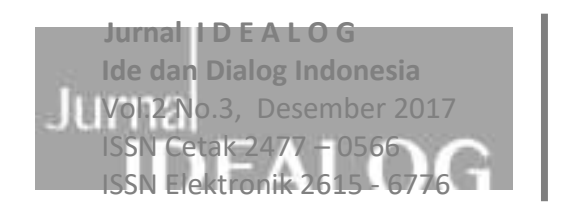

\begin{tabular}{|l|l|l|l|}
\hline & & & $\begin{array}{l}\text { warna, kondisinya sama dengan area tunggu di } \\
\text { titk A. }\end{array}$ \\
\hline $\mathrm{D}$ & $2-7$ & $\pm 80 \%$ & $\begin{array}{l}\text { Area ini lebih sepi dari area lain dengan luasan } \\
\text { yang juga lebih kecil dan kesan lebih gelap. } \\
\text { Penggunaan lantai vinyl motif parket dan sofa } \\
\text { hitam membuat ruangan ini terkesan tegas dan } \\
\text { menekan psikis wanita. }\end{array}$ \\
\hline
\end{tabular}

Tabel Hasil Pengamatan Pengaruh Warna di Ruang Tunggu Pada Wanita

Sumber : Analisa penulis (2017)

Kondisi diatas jika diamati dari sisi warna menunjukkan bahwa wanita lebih cenderung menempati warna-warna terang dan mencari arah yang memiliki pandangan pada warna yang tidak motonon, seperti ke area dinding dengan beberapa lukisan maupun ke sisi luar yang lebih terang meskipun warna yang dipakai tidak sepenuhnya warna gelap, tetapi warna hangat.

Pada pasien wanita yang terlihat, mereka lebih gelisah dan tampak kurang menikmati lingkungannya, karna secara tidak langsung, apa yang mereka lihat disekitarnya seperti sofa, coffee table dan elemen pembentuk interior disekitarnya kurang memiliki aksen.Pasien wanita lebih senang melihat kearah yang lebih terang dan berwarna lembut ataupun keluar jendela untuk melihat langit ataupun tumbuhan.

\subsection{Pengaruh Warna di Ruang Tunggu Pada Pasien Anak}

Poliklinik anak yang berada di titik A tidak menutup kemungkinan keberadaana anak menyebar di semua titik pengamatan. Hasil dari pengamatan pada anak terhadap warna adalah sebagai berikut:

\begin{tabular}{|c|c|c|l|}
\hline $\begin{array}{c}\text { Titik Area } \\
\text { Tunggu }\end{array}$ & $\begin{array}{c}\text { Jumlah } \\
\text { Wanita/orang }\end{array}$ & $\begin{array}{c}\text { Persentase teradap } \\
\text { total pengunjung }\end{array}$ & \multicolumn{1}{c|}{ Perilaku terhadap warna } \\
\hline A & $5-8$ & $\pm 50 \%$ & $\begin{array}{l}\text { Area ini merupakan area tungu poli anak, } \\
\text { sehingga anak yang sakit mendominasi di } \\
\text { area ini. Anak yang lebih suka melihat } \\
\text { warna yang atraktif cenderung rewel ketika } \\
\text { harus menunggu di area ini, beberapa anak } \\
\text { dalam beberapa waktu juga menangis } \\
\text { sehingga orang tua akan mengajaknya } \\
\text { berkeliling ke area yang lebih luas dengan } \\
\text { warna-warna terang disekitarnya. }\end{array}$ \\
\hline B & $5-10$ & $\pm 20 \%$ & $\begin{array}{l}\text { Di area cafe, anak-anak tidak banyak } \\
\text { memilih tempat duduk, namun kebanyakan } \\
\text { orang tua yang membawa anak memilih } \\
\text { duduk di dekat jendela degan view } \\
\text { pemandangan di luar. }\end{array}$ \\
\hline C & $2-5$ & $\begin{array}{l}\text { Anak-anak yang berada di area ini } \\
\text { umumnya ikut menunggu administrasi atau } \\
\text { ikut ibunya. Sangat jarang ditemui anak di } \\
\text { area ini, adapun anak-anak tersebut adalah } \\
\text { bayi usia 0-12 bulan, anak-anak yang } \\
\text { sudah dapat berjalan lebih banyak } \\
\text { menunggu di area sofa B atau berjalan- } \\
\text { jalan di sekitar area tunggu melihat warna- } \\
\text { warna yang mencolok pada beberapa } \\
\text { lukisan yang di pajang. }\end{array}$ \\
\hline
\end{tabular}




\begin{tabular}{|l|l|l|l|}
\hline D & $1-2$ & $\pm 5 \%$ & $\begin{array}{l}\text { Hampir tidak ada anak-anak di area ini, } \\
\text { adapun anak-anak saat pengamatan hanya }\end{array}$ \\
& & $\begin{array}{l}\text { ikut orang tuanya menunggu sebentar } \\
\text { kemudian seperti pada kasus sebelumnya } \\
\text { lebih memilih berkeliling di area rumah } \\
\text { sakit. }\end{array}$ \\
\hline
\end{tabular}

Tabel Hasil Pengamatan Pengaruh Warna di Ruang Tunggu Pada Anak Sumber : Analisa penulis (2017)

Dari kasus-kasus pada pengamatan tersebut, dapat diartikan bahwa kebutuhan anak akan warna sebagai penenang sebenarnya sangat dibutuhkan mengingat mereka aktif dan mudah rewel. Dengan warna yang ada pada ruang tungu RSIA Melida Bandung saat ini, terutama di area tunggu poli anak, belum dapat memberi efek psikologis sebagai penenang untuk anak-anak atau sekedar merasa nyaman. Justru dengan warnawarna yang elegan dan tegas tersebut membuat anak merasa lebih tertekan dan mudah bosan.

\subsection{Pengaruh Warna di Ruang Tunggu Pada Pengunjung non Pasien}

Pengunjung non pasien terutama pengantar pasien memiliki pengaruh terhadap pasien dimana pada kondisi tertentu, pengantar yang dapat menengkan kondisi pasien. Keberadaan pengantar tentu berdampingan dengan pasien, dalam arti posisi nya menyebar di seluruh titik.

Pengunjung wanita sebagai pengantar nmemiliki perilaku yang hampir sama dengan pasien wanita seperti yang sudah dijleaskan, yaitu mudah gelisah dan cenderung mencari arah yang lebih terang dan berwarna lembut. Sedangkan pengunjung pria sebagai pengantar ataupun pada saat ia menjadi pasien, memiliki perilaku yang lebih tenang, santai dan tidak terlalu mempermasalahkan lokasi duduk, hal ini di sebabkan karena menurut teori, warna-warna yang terdapat pada Rumah Sakit Ibu dan Anak Melinda Bandung merupakan warna-warna yang dirasa nyaman untuk pria. Hal ini dinilai positif jika pengantar pasien adalah pria sehingga pria dapat menularkan rasa tenangnya kepada pasien yang diantar, namun menjadi kurang positif ketika pasien dan pengantar adalah seorang wanita yang sama-sama mudah merasa gelisah.

\section{Kesimpulan}

Warna yang digunakan pada Rumah Sakit Ibu dan Anak Melinda Badung adalah kombinasi warna putih, coklat dan hitam dengan kesan elegan untuk mempertegas konsep galery dan hotel bintang lima yang diusung, sedangkan pengguna sebanyak $65 \%$ adalah wanita yang merasa lebih cocok dengan warna-warna yang lembut dan cerah. Untuk pengunjung terutama pasien anak-anak, ruang tunggu yang monoton dengan warna tersebut kurang menunjang, diamana sesuai karakter anak-anak dan kebutuhannya seharusnya lebih banyak warna-warna tenang dengan tune yang mengarah ke warna dingin agar dapat meredam kelinchan yang berlebihan dan membuat anak-anak lebih tenang.

Rekomendasi untuk penggunaaan warna untuk fungsi membantu usaha-usaha pelayanan tersebut dimana manusia dalam kondisi ini memiliki temperamen khusus yang penuh emosional dengan tetap mempertahankan konsep galery dan hotel bintang lima 
adalah dengan penambahan aksen warna dengan warna-warna yang direkomendasikan seperti terra cotta atau hijau emerald, turquoise, biru safir, flaminggo, atau merah labu.

Warna Asli Rumah Sakit Ibu dan Anak Melinda Bandung:

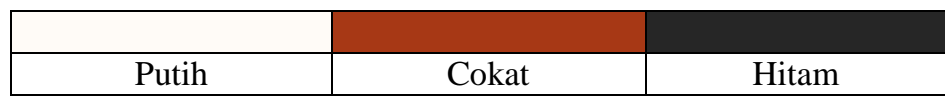

Tabel Warna Asli RSIA Melinda Bandung

Sumber : Analisa Penulis (2017)

Pilihan Penambahan Warna Aksen:

\begin{tabular}{|l|c|c|c|c|c|}
\hline terra cotta & hijau emerald & turquoise & biru safir & flaminggo & merah labu \\
\hline
\end{tabular}

Tabel Pilihan Warna Aksen Pada Teori Warna

Sumber : Warna - Teori dan Kreativitas Penggunanya edisi -2 (2001)

Jika ditinjau dari visi misi dan identitas Rumah Sakit Ibu dan Anak Melinda Bandung, Warna biru dan turuannanya, terutama biru muda yang merupakan warna pastel dirasa lebih cocok untuk digunakan sebagai warna aksen.

\begin{tabular}{|c|c|c|c|}
\hline & & & \\
\hline Putih & Cokat & Hitam & Biru Muda \\
\hline
\end{tabular}

Tabel Hasil Warna Rekomendasi Untuk RSIA Melinda Bandung Sumber : Analisa Penulis (2017)

\section{Referensi}

[1] A. Sulasmi Darmaprawira W. Warna - Teori dan Kreativitas Penggunanya edisi -2, Penerbit ITB, Bandung (2001)

[2] Darto, Ahmad, Psikologi Kebidanan - Analisis Perilaku Wanita Untuk Kesehatan, Salemba Medika, Bandung (2012)

[3] Peraturan Menteri Kesehatan RI No. 24 Tahun 2016 Tentang Persyaratan Teknis Bangunan dan Prasarana Rumah Sakit

[4] UU RI Nomor 23 Tahun 2002 pasal 1 Ayat 1

[5] Wicaksono, A.A. \& Trisnawati, E. Teori Interior, Penerbit Griya Kreasi, Jakarta Timur (2014) 